Received 22.03.2018

Reviewed 11.06 .2018

Accepted 14.06.2018

A - study design

B - data collection

C - statistical analysis

D - data interpretation

$\mathbf{E}$ - manuscript preparation

F - literature search

\section{Assessment of drinking water quality of Kopiliq village in Skenderaj, Kosovo}

\footnotetext{
1) University of Mitrovica "Isa Boletini”, Faculty of Food Technology, Mitrovica, Kosovo; e-mail: mensur.kelmendi@umib.net; sadija.kadriu@umib.net; milaim.sadiku@umib.net; mehush.aliu@umib.net; xsadriu@gmail.com

2) University of Mitrovica "Isa Boletini", Faculty of Geosciences, 40000, Mitrovica, Kosovo; e-mail: sylejman.hyseni@umib.net
}

For citation: Kelmendi M., Kadriu S., Sadiku M., Aliu M., Sadriu E., Hyseni S.M. 2018. Assessment of drinking water quality of Kopiliq village in Skenderaj, Kosovo. Journal of Water and Land Development. No. 39 p. 61-65. DOI: 10.2478/jwld2018-0059.

\begin{abstract}
It is known that groundwater is an indispensable element without which we cannot think of life on our planet. It is also known that around $50 \%$ of the world's population uses drinking water sources to meet the existential needs. Increment of population, industrial development and environmental pollution in our globe, directly or indirectly, has not only impacted groundwater pollution, but has also contributed in reducing the amount of water needed to meet elementary needs of man and other living beings. Therefore, for humanity, proper monitoring of groundwater became a priority in order to identify pollution levels and prevention of potable water sources from eventual contamination. Although Kosovo has sufficient water reserves, in most villages in the absence of infrastructure, the rural population in most cases for the purpose of providing drinking water uses water wells and springs. For this very reason, we have assessed the quality of the water wells located in the central part of Kosovo, in the village Kopiliq of Skenderaj. To assess the water quality of these wells, we have set the monitoring network, based on five monitoring points (wells), determining the organoleptic, physico-chemical parameters and bacteriological characteristics. Obtained sample results were compared with the reference values of Directive 98/83/EC - for drinking water quality and some wells resulted in exceeding the reference values for nitrite, chloride and total dissolved solids (TDS) whereas all wells were highly contaminated with bacteria.
\end{abstract}

Key words: drinking water quality, Kopiliq village, monitoring points, wells

\section{INTRODUCTION}

Already, it is concluded that half of humans, living on our planet, every day have a high absence of drinking water reserves, although $71 \%$ of the surface of this planet is covered with water. The quality as well as the quantity of clean water supply is of vital significance for the welfare of humanity [KHEIFI, BoudouKHA 2018]. Therefore, the pollution of water and the environment around it is dangerous not only for humans, but also for other living beings, the existence of which cannot be thought without drinking water. Apart from the essential role of extinction of humans and other living beings, water is also necessary for the maintenance of personal and general hygiene as its pollution directly affects human health, such as: metabolism, viral and parasitic diseases, illness and bone deformation etc. It is sufficient a single exposure to a pathogenic microorganism to cause disease. Given these characteristics, no tolerance limits can be set for pathogenic microbes. Water intended for human consumption, food preparation or personal hygiene should not contain any pathogenic microorganism [US EPA 2012].

The physico-chemical quality of drinking water is also based on hydrogeological criteria. These criteria relate to the type of water layer feeding, the composition and structure of the terrain, the level of protection of the water layer 
etc. [FAWELl, NiEUWENHUIJSEN 2003]. In addition to the physico-chemical parameters such as temperature, turbidity, $\mathrm{pH}, \mathrm{KMnO}_{4}$ consumption, free chlorine, chlorides, ammonia, nitrites, nitrates, total dissolved solids (TDS), electrical conductivity, sulphates, hardness etc., for determining the quality of drinking water, it is important to consider the fulfilment of organoleptic, physico-chemical and microbiological requirements. Water meets the quality standards for drinking purpose only after physico-chemical and microbiological analysis has taken place, and these analyses are in correlation with the standard values of local and foreign directives related to drinking water.

Water contaminated by microorganisms spreads epidemic and various microbial infections. Therefore, it is necessary to find different methods for usual drinking water examination for the purpose of identifying the presence or absence of faecal matter. Although now it is possible to detect the presence of many pathogenic microorganisms in water using isolation and counting methods which are often complex and time consuming [US EPA 2012]. The presence of faecal matter in the drinking water is sufficient to convince us that the same water is contaminated with other intestinal pathogenic microorganisms, whereas their absence indicates the opposite, for clean water [YODER et al. 2008]. Therefore, the basic purpose of this scientific research was to monitor and assess the quality of the water wells in the village of Kopiliq, Skenderaj municipality.

\section{MATERIAL AND METHOD}

As water is the basic element and most villages have water wells as the only drinking water source motivated us to do this limited research within a small geographic area of the water wells of Kopiliq village of Skenderaj, in Kosovo. The municipality of Skenderaj is located in the central part of Drenica and extends to an area of $368 \mathrm{~km}^{2}$. In the northern part is bordered by the municipality of Mitrovica, in the east with municipality of Vushtrri, southwest with Drenas and Klina, while in the west it is bordered by Municipality of Burim. This municipality extends over the geographic coordinates: $42^{\circ} 44^{\prime} 48 \mathrm{~N}$ and $20^{\circ} 47^{\prime} 10 \mathrm{E}$. The territory of the Skenderaj municipality has a hilly and mountainous configuration at an altitude of 500-700 m. The relief is mild and is crisscrossed with small river valleys, dominated by the continental climate which is characterized by severe winters, dry summers with high temperatures and low precipitation but having rich flora and fauna. Average relative humidity according to seasons: in summer $62.5 \%$, in spring $68.5 \%$, in fall $72.6 \%$ and in winter $81.6 \%$. Based on 1974 data the urban lands of Skenderaj municipality, generally are characterized by sandy, humus and smonitsa soils. Our research and monitoring area is the water of the wells of the village Kopiliq, which geographically lies in the south-western part of Skenderaj.

The monitoring network includes five monitoring points $\left(S_{1}, S_{2}, S_{3}, S_{4}\right.$ and $\left.S_{5}\right)$, five water wells from which the families of this village are supplied. The monitoring network and coordinates of the five selected locations for this research have been presented in Figure 1 and Table 1.

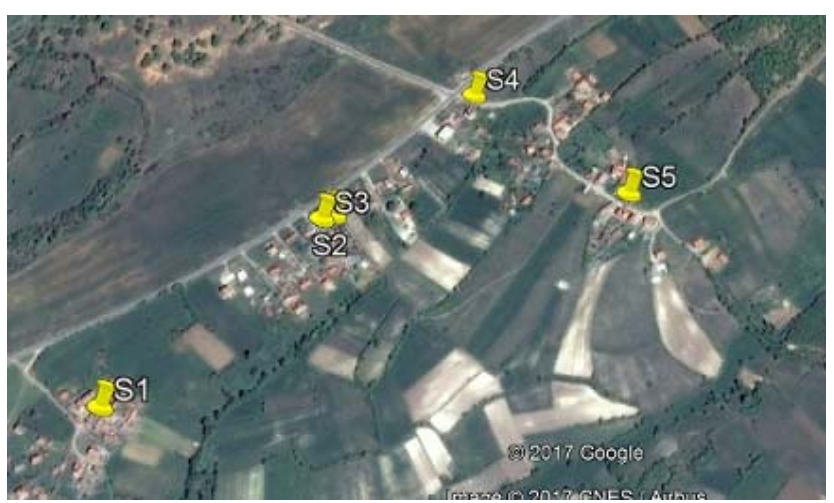

Fig. 1. Monitoring network in the research area; source: Image (C) 2017 CNES / Airbus

Table 1. Monitoring points and their coordinates

\begin{tabular}{|c|c|c|c|}
\hline $\begin{array}{c}\text { Sampling } \\
\text { points }\end{array}$ & $\begin{array}{c}\text { Geographic } \\
\text { latitude N }\end{array}$ & $\begin{array}{c}\text { Geographic } \\
\text { longitude W }\end{array}$ & $\begin{array}{c}\text { Height above sea } \\
\text { level (m) }\end{array}$ \\
\hline $\mathrm{S}_{1}$ & $42^{\circ} 41^{\prime} 49.88^{\prime} \prime$ & $20^{\circ} 42^{\prime} 11.85^{\prime}$ & 590 \\
\hline $\mathrm{S}_{2}$ & $42^{\circ} 41^{\prime} 58.81^{\prime}$ & $20^{\circ} 42^{\prime} 23.95^{\prime}$ & 607 \\
\hline $\mathrm{S}_{3}$ & $42^{\circ} 41^{\prime} 58.64 ”$ & $20^{\circ} 42^{\prime} 23.21^{\prime}$ & 607 \\
\hline $\mathrm{S}_{4}$ & $42^{\circ} 42^{\prime} 05.01^{\prime}$ & $20^{\circ} 42^{\prime} 32.07^{\prime}$ & 620 \\
\hline $\mathrm{S}_{5}$ & $42^{\circ} 41^{\prime} 59.56^{\prime}$ & $20^{\circ} 42^{\prime} 41.63^{\prime}$ & 628 \\
\hline
\end{tabular}

Explanations: $\mathrm{S}_{1}-\mathrm{S}_{5}=$ sampling points as in Fig. 1 .

Source: own elaboration.

The monitoring was done from 10-15 August 2017 as the water level in the monitored wells in this month is lower because of the high temperatures and scarce rainfall, which are characteristic of the summer season.

The method of sampling, the quantity of the sample collected for determination of certain parameters, the mode of transport and the maximum time the sample can stand before performing chemical analysis was done according to the ISO methods [ISO 5667 - 2006, 2009, 2012]. Water quality control requires physico-chemical and microbiological analysis as well as adequate selection of quality parameters. Water quality assessment is not only relevant for the analysed parameters but also to the sampling method, storage during transport and prior to the analysis [WHO 2011]. The polyethylene containers with which the water samples were taken are suitable for the analysis of the most common physico-chemical parameters, while for microbiological analyses sterilized glass containers were used.

Samples were taken every day and the mean + SD values were presented in the Table 2. For determination of organoleptic parameters such as aroma, taste and colour, the examination of which is done through the sensory organs, we have applied the comparative and visual methods. For determination of the physico-chemical parameters, in the laboratory of analyses were implemented these methods: potentiometric - $\mathrm{pH}$ value and electrical conductivity; nefelometric - turbidity, photometric - ammonia, nitrites and nitrates; volumetric (titration) - consumption of $\mathrm{KMnO}_{4}$, chlorides, sulphates, free chlorine and hardness.

In addition to the organoleptic and physico-chemical parameters, we have also analysed and presented the microbiological parameters. Samples were sent in the lab within the same day not exceeding $4^{\circ} \mathrm{C}$ while transport for microbiological analysis. Standard plate count (SPC) bac- 
teria at $37^{\circ} \mathrm{C}$ was done in petri plates which were incubated for 48 hours. The determination of the total number of living bacteria in $1 \mathrm{~cm}^{3}$ of the sample taken for analysis was done after incubation. The total number of bacteria is less useful for detection of faecal contamination, after numbering all kinds of microbes that are able to develop at a temperature of $37^{\circ} \mathrm{C}$.

However, the continuous determination of the number of bacteria in the drinking water samples is very useful, as it is the first indicator of a contamination [FAWELL, STANDFIEL 2001]. In microbiology, the colony forming unit (CFU) is a unit used to evaluate the total number of bacteria or fungal cells in a sample.

\section{RESULTS AND DISCUSSION}

Results of physico-chemical and microbiological analysis of wells water samples collected during 10-15 August 2017 were presented in Table 2. For the assessment of water quality of wells samples, we were based on the reference values of Directive 98/83/EC - on Drinking Water Quality [Council Directive 98/83/EC] which is in correlation with Administrative Instruction No. 16/2012 of the Republic of Kosovo for the quality of water for human consumption and the World Health Organization on Drinking Water Quality Guidelines have been adopted [WHO 2011].

Temperature. Water temperature differs in particular wells even the samples were taken the same days. The summer season is hot in this region but the near standard values are due to wells depths.

Even though the observed temperature didn't exceed $15.1^{\circ} \mathrm{C}$ are slightly over the standard value as seen on Table 2 .

Aroma. Water wells samples didn't have aroma except for $S_{1}$ which is a clear indication of bacterial contamination. Water from this well is not suitable for drinking regarding aroma which has to be confirmed from microbiological analysis.

Taste. Water in general is tasteless and any other taste state indicates that it has undergone pollution. All water samples fulfil this criterion.

Colour. Most important organoleptic factor for drinking is colour which is obvious to consumers. As water is colourless any other colour can result from ions, soil and plants. The water well on $\mathrm{S}_{2}$ was slightly coloured which was caused by clay.

Turbidity. As a measure of cloudiness of a water sample turbidity represents the suspended solids. The observed turbidity in the water wells sample was between 0.61 to 10.2 NTU whereas the standard is 2.4 NTU for drinking water. The sampling point $\mathrm{S}_{2}$ had excess water turbidity 10.2 NTU, which makes it not suitable for drinking purpose.

pH. Wells water samples had a pH 6.77 to 7.39 which was within the standard values and makes it suitable for drinking purposes.

Consumption of $\mathrm{KMnO}_{4}$. Being a measure of water organic matter is an indicator of overall pollution. The results were from 4.034 to $5.034 \mathrm{mg} \cdot \mathrm{dm}^{-3}$ and within the standard. Low consumption level clearly shows that there is no direct pollution of water wells.

Free chlorine. Represent the amount of chlorine that is active in the water and disinfect it. The amount of free chlorine in the drinking water has to be $0.2 \mathrm{mg} \cdot \mathrm{dm}^{-3}$ when consumed. Water wells were not chlorinated thus their values of free chlorine were always zero.

Chlorides. Dissolved chloride in surface waters occurs naturally from the geology but high concentrations typically result from runoff of de-icing salts applied to road surfaces. Chloride is a good conservative element to use for quality assurance in a mass balance model because no natural biological or chemical processes remove or add chloride to the surface water [BOUSLAH et al. 2017].

Table 2. Mean values of physico-chemical parameters and bacteriological characteristics of wells water samples

\begin{tabular}{|c|c|c|c|c|c|c|c|c|c|c|c|c|}
\hline \multirow{2}{*}{ Parameter } & \multirow{2}{*}{ Unit } & \multirow{2}{*}{$\begin{array}{l}\text { Standard } \\
\text { value }\end{array}$} & \multicolumn{10}{|c|}{ Sampling point } \\
\hline & & & $\mathrm{S}_{1}$ & $S D$ & $\mathrm{~S}_{2}$ & $S D$ & $\mathrm{~S}_{3}$ & $S D$ & $\mathrm{~S}_{4}$ & $S D$ & $\mathrm{~S}_{5}$ & $S D$ \\
\hline Temperature & ${ }^{\circ} \mathrm{C}$ & $8-12$ & 15.1 & 0.87 & 12.8 & 1.03 & 13 & 0.93 & 13 & 1.26 & 13.6 & 0.68 \\
\hline Aroma & - & without & with & - & without & - & without & - & without & - & without & - \\
\hline Taste & - & without & without & - & without & - & without & - & without & - & without & - \\
\hline Colour & scale Pt-Co & $10.0-20.0$ & without & - & turbid & - & without & - & without & - & without & - \\
\hline Turbidity & NTU & $1.2-2.4$ & 1.95 & 0.02 & 10.2 & 0.13 & 0.65 & 0.03 & 0.61 & 0.02 & 0.20 & 0.01 \\
\hline $\mathrm{pH}$ value & - & {$[6.5 ; 9.5]$} & 7.031 & 0.11 & 6.77 & 0.25 & 6.92 & 0.19 & 7.39 & 0.15 & 7.21 & 0.09 \\
\hline Consumption of $\mathrm{KMnO}_{4}$ & $\mathrm{mg} \cdot \mathrm{dm}^{-3}$ & $8-12$ & 4.034 & 0.02 & 5.043 & 0.03 & 4.034 & 0.01 & 4.706 & 0.02 & 4.370 & 0.01 \\
\hline Free chlorine $\left(\mathrm{Cl}_{2}\right)$ & $\mathrm{mg} \cdot \mathrm{dm}^{-3}$ & 0.2 & $<0.2$ & - & $<0.2$ & - & $<0.2$ & - & $<0.2$ & - & $<0.2$ & - \\
\hline Chlorides $\left(\mathrm{Cl}^{-}\right)$ & $\mathrm{mg} \cdot \mathrm{dm}^{-3}$ & 250 & 224 & 5.78 & 160 & 4.06 & 221 & 3 & 433 & 3.67 & 228 & 1.73 \\
\hline Ammonia $\left(\mathrm{NH}_{4}^{+}\right)$ & $\mathrm{mg} \cdot \mathrm{dm}^{-3}$ & 0.5 & 0.01 & 0.003 & 0 & - & 0.03 & 0.001 & 0.05 & 0.004 & 0.02 & 0.0016 \\
\hline Nitrites $\left(\mathrm{NO}_{2}^{-}\right)$ & $\mathrm{mg} \cdot \mathrm{dm}^{-3}$ & 0.1 & 0.006 & 0.0019 & 0 & - & 0.004 & 0.0014 & 2 & 0.03 & 0.003 & 0.012 \\
\hline Nitrates $\left(\mathrm{NO}_{3}^{-}\right)$ & $\mathrm{mg} \cdot \mathrm{dm}^{-3}$ & 50 & 0.3 & 0.34 & 0 & - & 3.8 & 0.41 & 2.1 & 0.19 & 1.3 & 0.371 \\
\hline Total dissolved solids (TDS) & $\mathrm{mg} \cdot \mathrm{dm}^{-3}$ & $800-1000$ & 977 & 3.51 & 762 & 2.67 & 815 & 3.11 & 1048 & 2.25 & 1256 & 3.92 \\
\hline Electrical conductivity & $\mu \mathrm{S} \cdot \mathrm{cm}^{-1}$ & 2500 & 1538 & 2.93 & 1157 & 3.34 & 1240 & 3.64 & 1587 & 3.81 & 1903 & 2.88 \\
\hline Sulphates $\left(\mathrm{SO}_{4}{ }^{2-}\right)$ & $\mathrm{mg} \cdot \mathrm{dm}^{-3}$ & 250 & 85.22 & 2.1 & 68.86 & 1.18 & 10.94 & 3.2 & 48.39 & 2.75 & 83.53 & 3.65 \\
\hline Hardness & $\mathrm{dH}$ & 30 & 13.32 & 1.5 & 10.976 & 2.31 & 28.46 & 1.66 & 11.2 & 2.5 & 12.64 & 1.85 \\
\hline SPC bacteria & $\mathrm{CFU} \cdot \mathrm{cm}^{-3}$ & 20 & $60 \cdot 10^{3}$ & 1.22 & $51 \cdot 10^{3}$ & 2.82 & $50 \cdot 10^{3}$ & 0.7 & $56 \cdot 10^{3}$ & 3.67 & $50 \cdot 10^{3}$ & 3 \\
\hline
\end{tabular}

Explanations: $\mathrm{S}_{1}-\mathrm{S}_{5}=$ sampling points as in Fig. 1 .

Source: own study. 
Their range was from 160 to $433 \mathrm{mg} \cdot \mathrm{dm}^{-3}$ with $4 \mathrm{sam}$ ples exceeding the standard $250 \mathrm{mg} \cdot \mathrm{dm}^{-3}$. The level of chlorides in water well $\mathrm{S}_{4}$ is dangerous not only for human health but also for irrigation and is not allowed to be used without prior treatment. Therefore, during the chlorination process of these wells, caution should be taken, as inadequate treatment may result in increased concentration of chlorides in water.

Ammonia. The concentration of ammonia in water wells was from 0 to $0.05 \mathrm{mg} \cdot \mathrm{dm}^{-3}$ which is within the maximum allowed level for drinking water $0.5 \mathrm{mg} \cdot \mathrm{dm}^{-3}$.

Nitrite. The concentration of nitrite was low except for well $\mathrm{S}_{4}$ which has a significant overflow with a concentration of $2 \mathrm{mg} \cdot \mathrm{dm}^{-3}$ (the recommended value is 0.1 $\left.\mathrm{mg} \cdot \mathrm{dm}^{-3}\right)$. Nitrite and chlorides are in very high concentration on the same well, so this phenomenon has occurred because nitrites are present in groundwater due to the spread of bacteria from faecal contamination, agricultural production, poor sewage network, presence of animal stalls near water well. BAHROUN and BOUSNOUBRA [2007] have concluded in their study that the deterioration of water quality is caused by drainage of agricultural land as well as from household and industrial liquid wastes. The burden of these omissions is growing ever more, thus affecting the socio-economic development of the region.

Nitrates. In terms of contamination of drinking groundwater, the nitrate is the most problematic element. The natural nitrate concentrations in groundwater are generally lower than $10 \mathrm{mg} \cdot \mathrm{dm}^{-3}$, the highest levels generally result from the external discharges (leaching from agricultural land, leakage of wastewater collection networks) [BENRABAH et al. 2016].

Concentration of nitrates was in range from 0-3.8 $\mathrm{mg} \cdot \mathrm{dm}^{-3}$ and within the maximum allowed level for drinking water.

Total dissolved solids. Exceeding reference values of total dissolved solids (TDS) was encountered on wells $\mathrm{S}_{4}$ and $\mathrm{S}_{5}$. It is known that high TDS values in underground waters, in general, are not harmful to humans, but too high concentration may adversely affect the health of people suffering from kidney and heart diseases [GEETHA et al. 2008].

Electrical conductivity. Conductivity qualitatively reflects the status of inorganic pollution and is a measure of total dissolved solids and ionized species in the waters [BARAKAT et al. 2013]. The values of electrical conductivity are lower than standard value. High values indicate that pollution discharges indirectly have entered the well water or high concentration of dissolved electrolyte ion in well water which happened to wells $\mathrm{S}_{4}$ and $\mathrm{S}_{5}$ respectively.

Sulphates. The concentration of sulphates in water samples was very low from 48.39 to $85.22 \mathrm{mg} \cdot \mathrm{dm}^{-3}$ compared to reference value $250 \mathrm{mg} \cdot \mathrm{dm}^{-3}$. Regarding sulphates concentration water is suitable for drinking and reveals that no industrial activity was done in that mountainous area.

Water hardness. Calcium and magnesium ion content in water expressed as $\mathrm{mg} \mathrm{CaCO}_{3} \cdot \mathrm{dm}^{-3}$ represents water hardness. Wells water was with the reference value thus being soft water which is suitable for cleaning and drinking.
Bacteriological characteristics. These characteristics are the most important quality parameters for drinking water.

Standard plate count (SPC) bacteria. Bacteriological analysis of SPC were done at $37^{\circ} \mathrm{C}$ and recorded extremely high values in all wells water. The highest value was recorded in well $\mathrm{S}_{1}$ with $60 \cdot 10^{3} \mathrm{CFU} \cdot \mathrm{cm}^{-3}$ which compared to the standard $20 \mathrm{CFU} \cdot \mathrm{cm}^{-3}$ for drinking water clearly shows extreme bacterial contamination. Wells water wasn't chlorinated thus the presence of fecal coliforms and pathogenic bacteria is quite possible, making water non drinkable and dangerous for humans especially those with weakened immune system.

Such a phenomenon occurred because the protective sanitary measures were not respected, as near the drinking water wells there were stalls, sewerage network, toilets etc. Some states have modern water wells building codes, while in our country there are no specific guidelines for the construction of wells.

The wells are regulated according to the whims of individuals from rural families and the same state was with the water wells of Kopiliq village.

\section{CONCLUSIONS}

In this study five wells water of village Kopiliq used for drinking purpose were analyzed. From the results it could be concluded that the water quality regarding physico-chemical values are within the allowed values according to Directive 98/83/EC except for turbidity in well $\mathrm{S}_{2}$, TDS in well $\mathrm{S}_{5}$ and chlorides, nitrites and TDS in well $\mathrm{S}_{4}$.

Microbiological analyses indicate that water hasn't undergone disinfection and all wells are contaminated with bacteria. Well water $\mathrm{S}_{4}$ is not allowed for drinking purposes nor irrigation without special pretreatment whereas it is an immediate necessity to disinfect water of all other wells before any domestic use. Stalls and sewerage network near water well $\mathrm{S}_{4}$ are the cause of contamination.

Competent state institutions in Kosovo are required to draw up special projects for the distribution of the drinking water supply network, not only for the inhabitants of the village of Kopiliq, where pollution has been identified, but also for other rural residents in Kosovo because only in this way with a constant monitoring and care can be preserved and protected, not only clean water, but also the health of thousands of residents of Kosovo.

\section{REFERENCES}

Administrative Instruction no.16/2012 on the Water quality for Human Consumption, was approved on 108 meeting of the Government of the Republic of Kosovo with the decision no.05/2012, date 14.12.2012.

BAHROUN S., BOUSNOUBRA K.H. 2007. Evaluation de l'indice de pollution organique dans les eaux naturelles cas de la région d'El Taref (nord-est Algérien) [Evaluation of the organic pollution index in the natural waters of the El Taref region (northeast Algeria)]. Larhyss Journal. No. 9 p. 171-178.

BaraKat A., El Baghdadi M., MEdDah R., RAis J., NADEM S., AFDALI M. 2013. Evaluation of water quality in open chan- 
nels flowing through Beni-Mellal City (Morocco). Journal of Water and Land Development. No. 19 pp. 3-11.

Benrabah S., Attoui B., Hannouche M. 2016. Characterization of groundwater quality destined for drinking water supply of Khenchela City (eastern Algeria). Journal of Water and Land Development. No. 30 p. 13-20.

Bouslah S., DJemili L., Houichi L. 2017. Water quality index assessment of Koudiat Medouar Reservoir, northeast Algeria using weighted arithmetic index method. Journal of Water and Land Development. No. 35 p. 221-228.

Council Directive 98/83/EC of 3 November 1998 on the quality of water intended for human consumption.

Fawell J., Nieuwenhuijsen M. 2003. Contaminants in drinking water. British Medical Bulletin. Vol. 68 p. 199-208.

Fawell J., Standfiel G. 2001. Drinking water quality and health. In: Pollution: Causes, effects and control. Ed. R.M. Harrison 4th ed. London. Royal Society of Chemistry p. 59-81.

Geetha A., Palanisamy P.N., Sivakumar P., Ganaesh P., Sujatha M. 2008. Assessment of underground water contamination and effect of textile effluents on Noyyal River basin in and around Tiruppur Town, Tamilnadu. E-Journal of Chemistry. Vol. 5. No. 4 p. 696-705. DOI 10.1155/2008/ 394052.
ISO 5667-1:2006. Water quality - Sampling - Part 1: Guidance on the design of sampling programs and sampling techniques.

ISO 5667-3:2012. Water quality - Sampling - Part 3: Preservation and handling of water samples.

ISO 5667-11:2009. Water quality - Sampling - Part 11: Guidance on sampling of groundwater.

KHEIFI S., BoudouKha A. 2018. Multivariate statistical characterization of groundwater quality in Fesdis, East of Algeria. Journal of Water and Land Development. No. 37 p. 65-74.

US EPA 2012. Microbial risk assessment guideline: Pathogenic microorganisms with focus on food and water. Environmental Protection Agency. FSIS Publication. No. USDA/FSIS/2012001; EPA Publication. No. EPA/100/J12/001 pp. 207.

WHO 2011. Guidelines for drinking-water quality. 4th ed. Geneva. World Health Organization. ISBN 9789241548151 pp. 541.

Yoder J.S., Hlavsa M.C., Craun G.F., Hill V., Roberts V., Yu P.A., Hicks L.A., AleXANDer N.T., CAlderon R.L., RoY S.L., BEACH M.J. 2008. Surveillance for waterborne disease and outbreaks associated with recreational water use and other aquatic facility-associated health events - United States, 2005-2006. Morbidity and Mortality Weekly Report. Vol. 57(9) p. 1-29.

\section{Mensur KELMENDI, Sadija KADRIU, Milaim SADIKU, Mehush ALIU, Edona SADRIU, Sylejman M. HYSENI}

\section{Ocena jakości wody pitnej we wsi Kopiliq koło miasta Skenderaj w Kosowie}

\section{STRESZCZENIE}

Wiadomo, że wody gruntowe są elementem niezbędnym do życia na naszej planecie. Wiadomo także, że $50 \%$ populacji świata korzysta z ujęć wody pitnej dla zapewnienia swoich potrzeb egzystencjalnych. Wzrost liczby ludności, rozwój przemysłu i zanieczyszczenie środowiska na Ziemi przyczyniają się, pośrednio bądź bezpośrednio, do zanieczyszczenia wód podziemnych i do ograniczenia ilości wody potrzebnej do zaspokojenia elementarnych potrzeb człowieka i innych istot żywych. Z tego powodu właściwy monitoring wód podziemnych stał się priorytetem niezbędnym do identyfikacji poziomu zanieczyszczeń i do zapobiegania ewentualnym zanieczyszczeniom źródeł wody pitnej. Choć Kosowo posiada wystarczające zasoby wodne, wobec braku infrastruktury, w większości wsi ludność wykorzystuje studnie i źródła do pozyskania wody pitnej. Kierując się tymi przesłankami, autorzy wykonali ocenę jakości wody studziennej w centralnej części Kosowa we wsi Kopiliq koło miasta Skenderaj. Utworzona została sieć monitoringu opartą na pięciu stanowiskach (studniach) i oznaczyono właściwości organoleptyczne, parametry fizyczne i chemiczne oraz bakteriologiczne wody. Wyniki analiz porównano z wartościami referencyjnymi Dyrektywy 98/83/EC dla jakości wody pitnej. W niektórych studniach stwierdzono przekroczone wartości stężenia azotanów, chlorków i sumy substancji rozpuszczonych (TDS). Wszystkie studnie były silnie zanieczyszczone bakteriami.

Słowa kluczowe: jakość wody pitnej, punkty monitoringu, studnie, wieś Kopiliq 